\title{
LYTIC ANTIBODIES ELICITED BY TRYPANOSOMA CRUZI INFECTION RECOGNIZE EPITOPES PRESENT ON BOTH BLOODSTREAM TRYPOMASTIGOTE AND EPIMASTIGOTE FORMS OF PARASITE.
}

Harumi A. TAKehara, Diva F. CARDOSO, Ana M.M. da SILVA \& I. MOTA

\begin{abstract}
SUMMARY
Sera of Chaga's disoase patients containing anti-T. cruzi lytic antibodies were submitted to affinty chromatography using Sepharose $4 B$ conjugated with antigen extracted from epimasigote or trypomastigote forms of the parasite. Epimastigotes were obtained from culture at the exponential growth phase and the trypomastigotes from blood of infected and immunosuppressed mice. Antigen of both parasite forms was obtained by sonication of the parasites followed by centrifugation. Both antigens were then conjugated to activated Sepharose $4 B$. Affinity chromatography was performed by passing sera from chagasic patients through an immunoadsorbent column containing either epimastigote or trypomastigote antigens. Antibodies bound to the column were eluted with cold $0,2 \mathrm{M}$ glycine buffer $\mathrm{pH} 2,8$. The eluted antibodies were analysed regarding their isotype and lytic activity. The results showed that anti-T. cruzi lytic antibodies present in sera from chagasic patients are mainly located in the $\operatorname{IgG}$ isotype and recognize epitopes present in both trypomastigote and epimastigote forms. A brief report of this work has already been published 12 .
\end{abstract}

KEY WORDS: Lytic antibody; Trypanosoma cruzi

\section{INTRODUCTION}

Chagas's disease is a complex clinical entity due to infection of man by an intracellular protozoan, Trypanosoma cruzi. which is transmitted by blood sucking insects.

T. cruzi has a complex life cycle and exists in different forms: the epimastigotes multiplying within the insect gut; the metacyclic trypomastigotes that are the infective forms in the invertebrate host; the amastigote multiplicative stage form within the mammalian cells and the trypomastigote form that circulates in the bloodstream of the vertebrate host.

Following infection with $T$. cruzi the immune system of the host responds with the formation of specific antibodies that are able to cause lysis of the trypomastigote forms in the presence of complement 3 . These antibodies are easily induced by infection with the parasite but are hardly induced by immunization with dead parasites and their presence in the infected host has been correlated with resistance 5.6 . The epitopes recognized by lytic antibodies are certainly present in the membrane of the trypomastigote but their presence in other forms of the parasite has not been investigated.

We present here results suggesting that lytic antibodies recognize epitopes present on both trypomastigote and epimastigote forms of the parasite.

Centro de Pesquisa e Formação em Imunologia da OMS/OPS. Instituto Butantan, São Paulo, Brasil

Address for correspondence: Dra. Harumi A. Takchara, Centro de Pesquisa e Formação em Imunologia da OMS/OPS. Instituto Butantan, Av. Dr. Vital Brasil, 1500. Caixa Postal 65 CEP 05504 São Paulo, SP., Brasil. 
TAKEHARA, H.A.; CARDOSO, D.F.; SILVA, A.M.M. da \& MOTA, I. - Lytic antibodies elicited by Trypanosoma cruzi infection recognize epitopes present on both bloodstream trypomastigote and epimastigote forms of parasite. Rev. Inst. Med. trop. São Paulo, 30(5):351-356, 1988

\section{MATERIAL AND METHODS}

Serum from chagasic patients: serum was obtained from blood collected from patients in the chronic phase of Chagas' disease with positive specific serological tests (complement fixation, haemagglutination and immunofluorescence). All sera from chagasic patients were inactivated at $56^{\circ} \mathrm{C}$ for 1 hour before use. When not used immediately the samples were stored at $-20^{\circ} \mathrm{C}$. Serum samples from 16 patients were studied. In some experiments the sera were tested individually (CS 1 to CS 5) or in pools (P1: CS 6, 7, 8, 9 and P2: CS 10,11, $12,13,14,15,16)$.

Antibody free bloodstream trypomastigotes: in order to suppress antibody production, mice were treated with cyclophosphamide $(350 \mathrm{mg} / \mathrm{kg}) 72$ hours after having received intraperitoneally an infective dose of 3 $x 10^{4}$ trypomastigotes. Seven days after infection the animals were bled by cutting the brachial plexus under light ether anaesthesia and the bloodstream trypomastigotes obtained as described by KRETTLI et al. ${ }^{7}$ with slight modifications: the blood was defibrinated with glass beads and the trypomastigote rich plasma separated by centrifugation for $10 \mathrm{~min}$ at $100 \mathrm{~g}$. The parasites were then washed by centrifugation for $20 \mathrm{~min}$ at $1000 \mathrm{~g}$ with phosphatebuffered saline (PBS) $0,15 \mathrm{M}$ pH 7,2 containing $10 \%$ normal mouse serum (NMS). To exclude the presence of membrane bound antibodies the trypomastigote were incubated with complement (fresh human serum) for $30 \mathrm{~min}$ at $37^{\circ} \mathrm{C}$. Only suspensions of parasites not lysed in the presence of complement were considered free of antibodies and were used to detect lytic antibodies. The final parasite suspension was adjusted with PBS containing $10 \%$ NMS to $4 \mathrm{x}$ $10^{6}$ trypomastigotes $/ \mathrm{ml}$.

Test for lytic antibodies: the antibody lytic activity was determined by complementmediated lysis according to KRETTLI ${ }^{5}$ with modifications. Twenty-five microliters of antibody free trypomastigotes suspension were added to $100 \mu \mathrm{l}$ of serum from chagasic patients or isolated anti-T.cruzi antibodies and the mixtures incubated at $37^{\circ} \mathrm{C}$ for $30 \mathrm{~min}$. After incubation aliquots of $25 \mu \mathrm{l}$ each were removed, mixed with an equal volume of fresh normal human serum or inactivated serum from the same complement donor and further incubated at $37^{\circ} \mathrm{C}$ for $60 \mathrm{~min}$. After that, the samples were immediately transferred to an ice bath, the number of motile trypomastigote determined in a Neubauer counting chamber and the percentage of lysis calculated. Duplicate samples were always used.

Preparation of $\mathrm{T}$. cruzi antigen for affinity chromatography: epimastigote antigen was obtained from T.cruzi culture in LIT medium at exponential growth phase containing more than $95 \%$ epimastigotes. The cultures were centrifuged at $2000 \mathrm{~g}$ for $15 \mathrm{~min}$ at $4^{\circ} \mathrm{C}$. The sediment was washed 4 times with $\mathrm{PBS}$ at 1500 $\mathrm{g}$ for $15 \mathrm{~min}$ at $4^{\circ} \mathrm{C}$.

Trypomastigote antigen was prepared from trypomastigotes isolated from the blood of cyclophosphamide-treated immunosuppressed mice as described in this paper. The isolated trypomastigotes were washed 3 times with PBS at $2000 \mathrm{~g}$ at $4^{\circ} \mathrm{C}$.

Both epimastigote and trypomastigote pellet containing about $10^{10}$ parasites were resuspended in $10 \mathrm{ml}$ of distilled water and sonicated at $60 \mathrm{~Hz}$ in a sonic dismembrator (Artex, Farmingdale, U.S.A.) for $2 \mathrm{~min}$ at $4^{\circ} \mathrm{C}$, and centrifuged $30 \mathrm{~min}$ at $10.000 \mathrm{~g}$. The sediment was discarded and the supernatant was lyophilized. This treatment resulted in about $30 \mathrm{mg}$ of material that was stored at $-20^{\circ} \mathrm{C}$.

Conjugation of $T$. cruzi antigens to activated Sepharose 4B: three grams of activated Sepharose 4B (Pharmacia Fine Chemicals; Uppsala, Sweden) were washed 3 times with $50 \mathrm{ml}$ of $10^{-3} \mathrm{~N} \mathrm{HCl}$. Thirty mg of lyophilized preparation were dissolved in $20 \mathrm{ml}$ of $0,1 \mathrm{M} \mathrm{NaHCO}$ buffer containing $0,5 \mathrm{M} \mathrm{NaCl}$ and gently mixed with Sepharose $4 \mathrm{~B}$ on a rotator at $4^{\circ} \mathrm{C}$ overnight. One $\mathrm{ml}$ of $1 \mathrm{M}$ ethanolamine was then added for 1 hour at room temperature to inactivate active groups. The Sepharose was separated by filtration in a Buchner funnel and the absorbance of the filtrate was determined at $280 \mathrm{~nm}$. The percentage of conjugation was estimated based on the difference between the initial and final absorbance of antigen solution. Conjugation was usually over $80 \%$. The Sepharose was packed in a column and submitted to 3 washing cycles to remove any non-covalently bound protein; each cycle consisting of a wash at $\mathrm{pH}$ 2,8 with $0,2, \mathrm{M}$ glycine buffer containing $1 \mathrm{M}$ $\mathrm{NaCl}$ followed by a wash at $\mathrm{pH} 8,0$ with $0,1 \mathrm{M}$ phosphate buffer containing $1 \mathrm{M} \mathrm{NaCl}$. In order to check for specificity a similar column 
TAKEHARA, H.A.; CARDOSO, D.F.; SILVA, A.M.M. da \& MOTA, I. - Lytic antibodies elicited by Trypanosoma cruzi infection recognize epitopes present on both bloodstream irypomastigote and epimastigote forms of parasite. Rev. Inst. Med. Irop. São Paulo, 30(5):351-356, 1988.

was prepared with Sepharose conjugated with bovine serum albumin (BSA).

Isolation of lytic antibodies: lytic antibodies were isolated by affinity chromatography using a $5 \times 2 \mathrm{~cm}$ column of Sepharose conjugated with either trypomastigote or epimastigote antigen preparations. One volume of serum from chagasic patients (usually $10 \mathrm{ml}$ ) was diluted in two parts of phosphate buffer $(0,15 \mathrm{M}$ pH 8,5) and slowly passed through the column under gravity force. The column was then washed with the same buffer until the optical density at $280 \mathrm{~nm}$ came to $O$. After passage through the column the serum from chagasic patients was restored to its original volume by positive pressure filtration. The antibodies were eluted with cold glycine buffer $(0,2 \mathrm{M} \mathrm{pH} 2,8)$ while keeping the column jacketed in an ice-bath.

Elution of the antibodies was followed by optical density at $280 \mathrm{~nm}$. Two $\mathrm{ml}$ fractions were collected in glass tubes kept in an ice-bath and immediately neutralized with $1 \mathrm{M}$ Tris buffer. The antibodies containing fractions were pooled, dialyzed against $\mathrm{pH} 7,4$ PBS for 24 hours and concentrated by positive pressure filtration to half the original serum volume. The isolated antibody was analysed regarding its isotype and lytic activity.

\section{RESULTS}

Samples of serum from chagasic patients were passed through an immunoadsorbent column containing either epimastigote or trypomastigote antigen and the lytic activity of the anti-T. cruzi antibodies eluted from each column was determined. The results of these experiments are shown in Table 1 . It can be seen that sera from chagasic patients had their lytic activity decreased after passage tnrough the immunoadsorbent column and that antibodies eluted from either trypomastigote or epimastigote column were able to lyse trypomastigotes in presence of complement. It can also be noted that in no case passage of the serum through either column caused complete removal of its lytic antibodies. Furthermore, even repeated passages of the chagasic serum through either the trypomastigote (Table 2) or the epimastigote column failed to completely remove its lytic activity. It can be further observed that passage of serum from chagasic patients through an immunoadsorbent column containing a non-related antigen such as BSA did not change its lytic activity (Table 1). In addition, it could also be observed that the material retained by the columns after passage of either sera from chagasic patients in BSA

TABLE 1

Lytic activity of antibodies isolated by affinity chromatography from serum of chagasic patients using immunoadsorbent columns containing trypomastigote or epimastigote antigen.

\begin{tabular}{|c|c|c|c|c|c|c|c|c|c|}
\hline \multirow[b]{3}{*}{ Serum Samples } & \multicolumn{3}{|c|}{$\begin{array}{c}\text { Sepharose } 4 \mathrm{~B}+ \\
\text { trypomastigote antigen }\end{array}$} & \multicolumn{3}{|c|}{$\begin{array}{c}\text { Sepharose } 4 \mathrm{~B}+ \\
\text { epimastigote antigen }\end{array}$} & \multicolumn{3}{|c|}{$\begin{array}{c}\text { Sepharose } 4 B+ \\
\text { BSA }\end{array}$} \\
\hline & \multicolumn{3}{|c|}{ \%of Lysis } & \multicolumn{3}{|c|}{$\%$ of Lysis } & \multicolumn{3}{|c|}{$\%$ of Lysis } \\
\hline & CS 1 & $\operatorname{CS} 2$ & CS 3 & CS 1 & $\mathrm{CS} 2$ & $\mathrm{CS} 3$ & CS 1 & $\operatorname{Cs} 2$ & $\mathrm{CS} 3$ \\
\hline $\begin{array}{c}\text { Before } \\
\text { Chromatography }\end{array}$ & 95 & 81 & 70 & 95 & 81 & 70 & 95 & 81 & 70 \\
\hline $\begin{array}{l}\text { After passage } \\
\text { in the column }\end{array}$ & 68 & 56 & 43 & 57 & 65 & 33 & 92 & 85 & 70 \\
\hline $\begin{array}{l}\text { Antibodies } \\
\text { eluted from the } \\
\text { column }\end{array}$ & 36 & 51 & 43 & 41 & 32 & 35 & 0 & 0 & 0 \\
\hline
\end{tabular}

Serum from chagasic patients was passed through a column of immunoadsorbent containing trypomastigote, epimastigote or BSA antigen. After passage in the column the serum samples, were returned to their original volume by positive pressure filtration. Antibodies were eluted with glycine buffer $\mathrm{pH} 2,8$ neutralized and concentrated to half of the original serum volume by positive pressure filtration. The serum samples before and after passage through the column and the eluted antibodies were used to sensitize trypomastigotes for complement-mediated lysis. An immunoadsorbent column containing BSA was used as a control for specificity. 
TAKEHARA, H.A.; CARDOSO, D.F.; SILVA, A.M.M. da \& MOTA, I. - Lytic antibodies elicited by Trypanosoma cruzi infection recog nize epitopes present on both bloodstream trypomastigote and epimastigote forms of parasite. Rev. Inst. Med. trop. São Paulo, 30(5):351-356, 1988.

\section{TABLE 2}

Removal of lytic antibodies by repeated passages of serum from chagasic patients through an immunoadsorbent column containing trypomastigote antigen.

\begin{tabular}{lccc} 
& \multicolumn{3}{c}{$\%$ Lysis } \\
\cline { 2 - 4 } & \multicolumn{3}{c}{ Sera from chagasic patients: } \\
\cline { 2 - 4 } & CS 4 & CS 5 & P 1 \\
& 95 & 94 & 81 \\
Before chromatography & 76 & 67 & 67 \\
After 1st passage & 57 & 44 & 41 \\
lst antibody & 70 & 63 & 63 \\
After 2nd passage & 0 & 0 & 0 \\
2nd antibody & 73 & 60 & 63 \\
After 3rd passage & 0 & 0 & 0 \\
3rd antibody & & & \\
\hline
\end{tabular}

$10 \mathrm{ml}$ of serum from chagasic patients were passed three times through an immunoadsorbent column containing trypomastigote antigen. After each passage the serum was returned to its original volume by positive pressure filtration. The lytic activity of the serum samples and of the isolated antibodies was determined after each passage. Results shown here were obtained using trypomastigote antigen but similar results were also obtained when epimastigote antigen was used. CS 4 and CS 5- sera from chagasic patients; $P 1$, pool of serum from chagasic patients.

coluinn or normal sera in trypomastigote or epimastigote columns contained significantly less protein than the specific antibodies eluted after passage of sera from chagasic patients in trypomastigote or epimastigote columns as estimated by O.D. at $280 \mathrm{~nm}$ (results not shown).

As shown in Table 2, a single passage of serum from chagasic patients through either trypomastigote or epimastigote column is sufficient to completely remove all the lytic antibodies able to react with antigens present on any one of these columns. In order to find out if a serum depleted of the antibodies able to react with one of the antigens would still have antibodies able to react with the other antigen, serum from chagasic patients was successively passed through both columns and its lytic activity determined after each passage. The results of these experiments depicted in Table 3 showed that adsorption of serum from chagasic patients with one the antigens was sufficient to remove the antibodies able to react with the other antigen.

Analysis of the antibodies isolated with epimastigote or trypomastigote antigen by immunodiffusion using monospecific antisera

\section{TABLE 3}

Double absorption of serum from chagasic patients with epimastigote and trypomastigote antigens.

Before Chromatography

After a single passage through epimastigote antigen

After an additional passage through trypomastigote antigen

After a single passage through trypomastigote antigen

After an additional passage through epimastigote antigen

Pool (P2) was first passed through the epimastigote column and immediately after through the trypomast:gote column or vice-versa.

The lytic activity of the single and doubled passed serum samples and that of the eluted antibodies was determined. P 2 - pool of serum from chagasic patients.

against human $\operatorname{IgG}, \operatorname{Ig} M, \operatorname{Ig} A, \operatorname{IgD}$ and $\operatorname{IgE}$ showed that only IgG was present.

\section{DISCUSSION}

The experiments showing that antibodies with lytic activity can be removed from serum of Chagas' disease patients by immunoadsorption with epimastigote antigen suggest strongly that lytic antibodies induced by infection are able to recognize epitopes present on epimastigote forms. The possibility that this adsorption could be due to contamination of the epimastigote culture with metacyclic trypomastigotes seems remote since the percentage of trypomastigote forms in our epimastigote preparation was very small $(5 \%)$. Furthermore, if removal of lytic antibodies by epimastigote antigen were due to contamination with trypomastigote antigen, the removal capacity of the epimastigote columns should be much less than that of the trypomastigote column and yet the efficiency of both columns was very similar.

The observation that even repeated passages through epimastigote and/or trypo- 
TAKEHARA, H.A.; CARDOSO, D.F.; SILVA, A.M.M. da \& MOTA, I. - Lytic antibodies elicited by Trypanosoma cruzi infection recognize epitopes present on both bloodstream trypomastigote and epimastigote forms of parasite. Rev. Inst. Med. trop. São Paulo, 30(5):351-356, 1988

mastigote immunoadsorbent columns did not completely remove the lytic antibodies from serum from chagasic palients demonstrate that many other epitopes able to react with lytic antibodies are not present in our antigenic preparations. This is probably due to many different reasons one of them being the action of the many proteases present in the parasites. However, it must be considered that it does not matter how little denaturated is the parasite antigen preparation since the conjugation technique by itself causes a great deal of denaturation. This was no surprise and could not be overcame as we were unable to obtain a fully antigenic preparation from either form of the parasite.

It is possible that the epitopes present on epimastigote and trypomastigote antigen preparations able to react with lytic antibodies have the same or very similar antigenic structures since a single passage of serum from chagasic parients through one of these antigenic preparations was sufficient to completely remove the lytic antibodies able to react with the other antigen. Indeed, when these antibodies were used to recognize epimastigote and trypomastigote antigen using the protein transfer techniquei4 many common antigens were recognized on both parasite forms (unpublished results).

In fact, previous studies on the antigenic composition of these forms have revealed the presence of many antigens common to all stages of the parasite although the existence of stage specific antigens has also been reported $11,1,15.13$. Recently, SNARY10 isolated a T. cruzi celı surface glycoprotein of $90.000 \mathrm{M} . \mathrm{W}$. able to protect mice against the acute phase of the infection that was present on all forms of the parasite. Furthermore, CHAO \& DUSANIC2 working with hybridoma cell line secreting monoclonal antibodies against $T$. cruzi found that some of these monoclonals reacted with antigens present on both epimastigote and trypomastigote forms. In fact, although obtained by immunization with metacyclic trypomastigotes most of these monoclonal antibodies did not display a metacyclic stage specificity which indicated a considerable degree of antigenic similarity among the different forms of T. cruzi.

Our results showing that "dead" trypomastigote antigens are still able to react with lytic antibodies seem contrary to the results of KRETTLI \& BRENER' 6 who reported that lytic antibodies react with living trypomastigotes but not with dead and fixed parasites. However, it is reasonable to think that treatment with fixatives denaturates the parasite antigens in a different and perhaps more drastic way than the technique for antigen extraction used here. Thus, fixation of parasites seems to destroy the ability of their antigens to react with lytic antibodies.

KRETTLI \& BRENER ${ }^{6}$ have also suggested that only an active infection is able to induce lytic antibodies. On the other hand, some recent reports showed that lytic antibodies can be induced after different immunization protocols using heat inactivated metacyclic trypomastigotes ${ }^{16}$ or even epimastigotes antigens 9 .

Our results showing that anti-T. cruzi lytic antibodies are mainly located in the IgG isotype agree with previous findings of ROMEIRO et al. ${ }^{8}$ who working with affinity chromatography with protein A obtained similar results. Conversely, KIPNIS et al. ${ }^{4}$ have been able to obtain an IgM with lytic activity from sera of patients in the chronic phase of Chagas disease. We can offer no explanation for this discrepancy.

These data and our present results suggest that more than one epitope present in the bloodstream trypomastigote is able to cause lysis of this parasite form on reaction with antibodies and that some of these epitopes are common to epimastigote culture forms. Further studies are required to elucidate this question.

\section{RESUMO}

\section{Anticorpos líticos induzidos por infecção pelo \\ Trypanosoma cruzi reconhecem epitopos presentes nas formas tripomastigotas e epimastigotas do parasita.}

Soro de pacientes com doença de Chagas na fase crônica foram submetidos a cromatografia de afinidade com Sepharose $4 \mathrm{~B}$ conjugada com um extrato antigênico obtido de formas epimastigotas ou tripomastigotas de T. cruzi: os epimastigotas foram obtidos de cultura na fase exponencial de crescimento e os tripomastigotas de sangue de camundongos infectados e imunossuprimidos. Os antígenos de ambas formas parasitárias foram obtidos por tratamento 
TAKEHARA, H.A.; CARDOSO, D.F.; SILVA, A.M.M. da \& MOTA, I. - Lytic antibodien elicited by Trypanosoma cruzi infection recog nize epitopes present on both bloodstream irypomastigote and epinastigote forms of parasite. Rev. Inst. Med. Irop. São Pauls, 30(5):351-356, 1988

dos parasitas por ultra-som, seguido de centrifugação.

A cromatografia de afinidade foi feita passando-se os soros chagásicos através de uma coluna de imunoadsorvente contendo antigenos de epimastigotas ou tripomaștigotas. Os anticorpos foram eluídos da coluna com tampão glicina $0,2 \mathrm{M}$ pH 2,8 a $4^{\circ} \mathrm{C}$. Os anticorpos eluidos foram analisados quanto ao seu isotipo e atividade lítica. Os resultados mostraram que os anticorpos anti-T. cruzi com atividade litica presentes em soros chagásicos estão localizados no isotipo IgG e reconhecem epitopos presentes tante nos tripomastigotas quanto nos epimastigotas.

\section{ACKNOWLEDGMENTS}

This work was supported by the Conselho Nacional de Pesquisas, Brazil (process $40.0695 / 85$ ). We thank Dr. Rodolfo Pereira Mendes for the generous supply of sera from chagaric patients and Mr. Carlos Jared for technical assistance.

\section{REFERENCES}

1. ARAÚJO, F.G. \& REMINGTON, J.S. - Characterization of stages and strain of Trypanosoma cruzi by analysis of cell membrane components. J. Immunol., 127: $855-859,1981$.

2. CHAO, D. \& DUSANIC, D.G. - Monoclonal antibodies to metacyclic stage antigens of Trypanosoma cruzi. Amer. J. trop. Med. Hyg., 34: 694-701, 1985.

3. KIERSZENBAUM, F. - Cross-reactivity of lytic antibodies against blood forms of Trypanosoma cruzi. J. Parasit., 62:134-135, 1976.

4. KIPNIS, T.L.; SUCUPIRA, M. \& DIAS DA SILVA; W. - Transformation of Trypanosoma cruzi trypomastigote bloodstream forms by immune IgM and its $\mathrm{Fab} \mu$ fragment into activators of the alternative complement pathway. Braz. J. med. biol. Res., 20: 105-114, 1987.

5. KRETTLI, A.U. - Efeito de anticorpos e do complemento sobre tripomastigotas sanguíneos de camundon- gos infectados com Trypanosoma cruzi. Belo Horizonte, 1978. (Tese de doutoramento - Instituto de Ciências Biológicas da Universidade Federal de Minas (ierais).

6. KRETTLI, A.U. \& BRENER, Z. - Resistance against Trypanosoma cruzi associated to anti-living trypomastigote antibodies. J. Immunol., 128: 2009-2012, 1982.

7. KRETTLI, A.U.; WEISS-CARRINGTON, P. \& NUSSENZWEIG, R.S. - Membrane-bound antibodies to bloodstream Trypanosoma cruzi in mice: strain differences in susceptibility to complement-mediated lysis. Clin. exp. Immunol., 37: 416-423, 1979.

8. ROMEIRO, S.A.; TAKEHARA, H.A. \& MOTA I. - Isotype of lytic antibodies in serum of Chagas' disease patients. Clin. exp. Immunol., 55: 413-418, 1984.

9. SEGURA, E.L.; BUA, J.; ROSENSTEIN DE CAM PANINI, A.; SUBIAS, E.; ESTEVA. M.; MORENO, M. \& RUIZ, A.M. - Monoclonal antibodies against the flagellar fraction of epimastigotes of Trypanosoma cruzi: complement - mediated lytic activity against trypomastigotes and passive immunoprotection in mice. Immunol. Lett., 13: 165-171, 1986.

10. SNARY, D. - Cell surface glycoproteins of Trypanosoma cruzi: protective immunity in mice and antibody levels in human chagasic sera. Trans. roy. Soc. irop. Med. Hyg., 77: 126-129, 1983.

11. SNARY, D. \& HUDSON, L. - Trypanosoma cruzi cell surface proteins: identification and isolation of one major glycoprotein. FEBS Letters, 100:166-170, 1979

12. TAKEHARA, H.A.; CARDOSO, D.F. \& MOTA, I. - Isolation of lytic antibodies with T. cruzi antigens. In: INTERNATIONAL CONGRESS OF IMMUNOLOGY, 6., Toronto, Canada, 1986. Abstracts. p. 649.

13. TEIXEIRA, M.M.G. \& YOSHIDA, N. - Stagespecific surface antigens of metacyclic trypomastigote of Trypanosoma cruzi identified by monoclonal antibodies. Molec. Biochem. Parasit., 18: 271-282, 1986.

14. TOWBIN, H.; STAHELIN, T. \& GORDON, J. Eletrophoretic transfer of protein from polyacrylamide gels to nitrocellulose sheets: procedure and some applications. Proc. nat. Acad. Sci. (Wash.), 76: 43504354, 1979.

15. YOSHIDA, N. - Surface antigens of metacyclic trypomastigote of Trypanosoma cruzi. Infect. Immun., 40: 836-839, 1983.

16. YOSHIDA, N. - Trypanosoma cruzi: recognition of trypomastigote surface antigens by lytic antisera from mice resistant to acute infection. Exp. Parasit., 61: 184$191,1986$.

Recebido para publicaço em 16/3/1988. 